\title{
New Deal for Minorities During the Great Depression
}

\author{
Fethia Braik \\ Faculty of Foreign Languages, University of Mohamed Ben Ahmed, Oran, Algeria
}

Email address:

fethiadove@yahoo.fr

\section{To cite this article:}

Fethia Braik. New Deal for Minorities During the Great Depression. Journal of Political Science and International Relations. Vol. 1, No. 1, 2018, pp. 20-24 doi: 10.11648/j.jpsir.20180101.13

Received: November 6, 2017; Accepted: November 20, 2017; Published: January 2, 2018

\begin{abstract}
During the Depression years, minority groups in the United States suffered more than the other segments of the American society. Yet, they were not the focus of New Dealers. One may wonder why and how were the lives of women, African Americans, and Indian Americans impoverished by the Great Depression enhanced under the New Deal. At the outset, NIRA codes emphasized women's inferiority to men since they reinforced traditional long-range place in the labor arena. African Americans, too, suffered more because of the NIRA. Likewise, the AAA and the CCC were administrated in segregationist manners. It was until 1935 onwards that things changed in favor of those minorities. Federal relief programs and agencies like the FERA, the WPA, and the NYA; and many other acts and executive orders contributed significantly in enhancing minorities' conditions of life during the Depression years.
\end{abstract}

Keywords: African Americans, Indian Americans, Women, Franklin Delano Roosevelt, Great Depression, New Deal

\section{Introduction}

The Great Depression for historians and economists is just like the Big Ben for physicians, an unprecedented event. The Great Depression is arguably the most severe economic downturn that the United States ever witnessed. It reflected various flaws within the American economic system. Millions of Americans could not retrieve their money from banks, thousands of farmers and homeowners lost their properties, and a quarter of the population was unemployed. In the midst of the despair and the impoverished situation during the Great Depression, Franklin Delano Roosevelt was elected President in 1932 without a specific program. Prior to his election, Roosevelt held strong belief that the Depression was caused by domestic factors, rather than by international ones, as Republicans believed.

For Roosevelt, the strength of the free market was the source of its malaise. He feared that capitalism would sweep away, in its undertow, freedom and democracy. Roosevelt relied on a highly eclectic group of advisors and academics of Columbia University, known as the brain trust, who patched together many programs, known as the New Deal, the end of which was to apply social values. Being aware of the origins of the Great Depression, made Roosevelt be more aware of the importance of the creation of the social welfare state. The brain trust furnished a platform whereby the country could get out of its economic quagmire. However, during its first years, the New Deal discarded minorities like women, African Americans, and Indian Americans. This paper elucidates how provisions within the New Deal programs devoted to those minority groups changed pleasantly in the course of time.

\section{New Deal and Minorities}

\subsection{New Deal for Women}

The New Deal made great advances for women and minorities. Although benefits reached women and other minorities too slowly, Roosevelt by nominating females in public offices initiated a new stage for them. The First Lady Eleanor Roosevelt and the first woman to hold a cabinet office as Secretary of Labor, Frances Perkins, motivated American women to lobby for social-welfare programs. Winifred D. Wandersee (1981) stated that the New Deal opened new doors to women. Women played an important role in and carrying out New Deal reforms. Perkins stated, in 1940 , that women won the struggle for industrial and social insurance programs. Such gain was ironically attributed to social reformers rather than to feminists. The New Deal, being a bleak catalog of contradictions, paradoxically made advances for women in some areas and limited them in others reinforcing the traditional societal pressures that 
characterized the era.

Since the industrial era, women's predominant issue was the tension between family and work that characterized their domestic and economic experiences. Because of the Depression, women faced a curious ambiguity. On the one hand, the Depression pushed women to work to meet the current economic pressures. On the other hand, women avoided wage work in the interest of jobs for men to foster unity within their families. New Deal reforms intensified this ambiguity since they preserved women's traditional longrange place in the labor arena. Wandersee (1999) emphasized this issue by referring to the NIRA. She stated that although the NIRA covered one-half of all employed women, it neglected those who were working in the worst conditions of jobs such as public services, domestic services, laundries, and dressmaking.

More importantly, NIRA codes did little good to women as 135 out of 233 codes established lower minimum wages for women as compared to those of men. The difference varied between $\% 10$ and $\% 20$. The codes also decreased the number of hours particularly for women and unskilled employees. Shorter work days culminated in lower wages; and wages of the better-paid workers were to be reduced to pay the lowerpaid workers. Yet, the codes had their blessings on women basically the Wagner Act. The Act, being the most influential labor legislation ever signed by an American president, fostered the foundation of organizations like Congress of Industrial Organizations (CIO) and the American Federation of Labor (AFL) to which women adhered increasingly during the 1930 s.

While women working in textiles, paper products, restaurants, laundries, and cigar and confectionary manufacturing affiliated to the AFL, women hiring heavy industries joined the CIO. Women in the automobile and the rubber industries suffered wages reduction and long working hours. It was thanks to the United Rubber workers, organized by the CIO, that wages increased twofold and the working hours decreased to eight hours per day. Nevertheless, discriminatory characteristic features such as sex-defined job categories, wage differentials, and the opposition of married women affiliations constituted most of contracts. In addition, unemployed women never received relief the same way unemployed men did. The New Deal did but reflect societal attitudes towards women, and never considered their issue more than temporary. The FERA, the WPA, and the National Youth Administration (NYA) ${ }^{1}$ never intended to see women more than servants and housewives. Out of the 372 thousands women employed on WPA projects about 185 thousands worked in canning and sewing. It was until July 1937 that the Household Service Demonstration Projects provided jobs such as teaching and demonstration for women. Two years thereafter, thousands of women received training; and thousands of trainers were placed with almost $100 \%$.

1 The NYA set forth programs to provide relief to young people who attended school. It also trained young people who were unemployed and did not attend school to prepare them for jobs in the future.
The WPA proved to be the most sympathetic to the needs of women among other relief agencies. Its projects tended to place women in white-collar occupations. One third of all women employed under the WPA projects were clerical, professional, and technical workers. Still, they were underrepresented and limited. For example, the resident educational camps, under the NYA, excluded women from higher achievements. They were put into limited channels of achievement discarding their potentialities. Thus, women's low economic status was reinforced. Likewise, their social security was dependent upon men. The Social Security Act of 1935 did not only exclude unemployed married women but also women working in farm labor and charitable and hospital services. It left one third of all employed married women without welfare relief.

On the other hand, another form of direct relief was incorporated within the Aid to Dependent Children. Women commuted work relief to ADC. Though the programs did not move beyond traditional status of women, they encouraged women to pursue careers in public life. Most of those who advocated for New Deal for women held important positions in federal government agencies. The "half-loaf" achievement was accepted by female reformers who viewed the limited opportunities for work, training, and social welfare as victories. The experience of women during the New Deal era can be seen as parallel to another group traditionally outside politics in the United States, Blacks. Both groups received unprecedented opportunities of employment, training, welfare security, and governmental activity, though limited.

\subsection{New Deal and Black Issues}

As for African Americans, historians acknowledged the emergence of the Civil Rights Movement to the New Deal. Before the Depression, African Americans suffered segregation. They could not hold positions in presidential administrations. They could not go to the same cafeterias as White federal employees. Cases revolving around racial segregation and violence issues were rejected in local and federal Courts. Many of them were deprived from their right to vote. During the depression, African Americans suffered hard as most of them lost their jobs. Many African American farmers and tenants lost their lands. Federal relief agencies rallied to sustain whites and ignored the blacks. When President Roosevelt assumed office, African Americans worried that they would undergo the same hardships and ignorance.

During its first hundred years, New Deal did little good to the African Americans. While NIRA codes enhanced white workers conditions, it did not only exclude many black workers from wage codes but it also left them at the mercy of their white employers. Likewise, the AAA was not administrated in favor of African Americans. Local officers discarded them from federal payments. White farmers denied proportionate shares of their black tenants and sharecroppers. The Civil Conservation Corps (CCC), too, was discriminatory. Although it accepted African Americans in its programs, it separated their campus from those of the Whites. 
Black leaders referred to the New Deal as the "Raw Deal". Similarly, the acronym NRA which stands for the National Recovery Administration was referred to as "Negroes Run Around" by African Americans. By 1934, things changed and Blacks were pleasantly surprised.

Lobbied by Eleanor Roosevelt, the National Association for the Advancement of the Colored People (NAACP) and civil rights organizations sought integration of more African Americans within New Deal programs. With important antisegregationist strenuous efforts of progressive New Dealers like Harold Ickes, Harry Hopkins, and Aubrey Williams, New Deal programs were applied with less racial bias. Thereafter, $30 \%$ of the jobs created by WPA was devoted to African Americans. Provisions provided relief to millions of African Americans, hired millions of them to work, and restored African American schools. Many teachers were put back to their jobs; and hundred thousand African Americans learnt to read and write. They could even write and perform plays. Though the Tennessee Valley Authority did not put blacks in construction work, other New Deal programs helped hire many skilled workers, keep their homes far from foreclosure; and offered fifty thousand farmers, sharecroppers, and tenants direct relief to buy farms.

In 1936, Roosevelt disintegrated the Jim Crow code and welcomed African Americans in the Democratic National Convention by raising the White House inclusion spirit. In addition, he created the "Black Cabinet" by appointing African Americans to important positions. E. Roosevelt, urged by Mary McLeod Bethune of the National Youth Administration, wrote a memo to the President on November $22^{\text {nd }}, 1941$ to persuade him to appoint an African American in a high position who would help decide upon issues related to the black community. She wrote,

I have been asked to call your attention to the importance of having a Negro in a position who can actually confer with the President occasionally on problems that are pertinent to Negroes, and who can have a very close affiliation with the Under- Secretaries of the President as to the Negro's cause.

About forty five African Americans were appointed to New Deal administrations. Historian Nancy J. Weiss (1983) stated that "the Black Cabinet was important to Blacks because it signified that the government was paying attention to them in ways that had never been the case before." They founded the Federal Council of the Negro Affairs whose target was to render the programs more responsive to the blacks' needs and issues. Recommendations were given to the First Lady who would urge their implementation. They could either amend or pass New Deal legislation although they have been trumped because of their resistance to Southerners' target to lynch Black people.

During the worst years of the Great Depression, lynching of African Americans spiked throughout Southern states. Both the white supremacy and the Jim Crow discriminatory laws hindered any efforts to realize justice in dealing with the lynching. Lynching Black people was "a vile form of collective murder .... a deliberate and definite disobedience of the Commandment, Thou shalt not kill" for Roosevelt, and he stated that he could by no means excuse those who condoned lynch law. Yet, he dismissed to pass a bill introduced by Senators Edward Costigan and Robert Wagner which would classify lynching as a federal crime in case state and local officials might fail. Walter White, the head of the National Administration for the Advancement of Colored People (NAACP) wrote a letter to the President to persuade him to pass anti-lynching legislation, but in vein. He wrote,

From reports which come to us from authentic sources in various parts of the country, the recent strenuous efforts to prevent lynchings have been due almost entirely to fear of federal legislation. These reports give ground for belief that should the Costigan-Wagner Bill fail of passage there will be new and bloody outbreaks which may result in a terrible situation.... We strongly urge that the President make the request of the leaders of Congress that the bill be voted for on prior to adjournment. We do not believe that there need any fear of a sustained filibuster.

When he was asked about, Roosevelt claimed that he did not want to dissipate Southern Democrats' votes which he might need to pass bills that would "keep America from collapsing." His refusal to pass the bill led Eleanor Roosevelt and Walter White to renew their pressure on the President. Governors, mayors, newspaper editors, judges, and private organizations, with White signed a petition to convince Roosevelt that the Costigan-Wagner Bill had a wide public support. The petition, however, was buried in the files of the White House as Roosevelt could not challenge his party leadership in Congress, although he held a strong private support to the bill. However, many of hallmark New Deal programs prescribed ant-lynching provisions.

A clear anti-lynching legislation was urgently recommended though it failed repeatedly in front of Congress because of filibuster by Southern Democrats. Such bill was never voted for during Roosevelt's presidency. Still, there was an overwhelmed certainty in the whole country that the president opposed bitterly racial segregation. The Roosevelts worked hard to enhance oppressed blacks' conditions. Frank Murphy, Roosevelt's Attorney General, established Civil Liberties Unit in the Department of Justice, which was designed to protect African Americans' civil rights. Murphy believed that what America had given to civilization, liberty, had to be given to all.

Lynching, mob violence, and other forms of civil liberties violations were subject to federal prosecutions under the Civil Rights Section of 1941. The latter became an important precursor that spurred the Civil Rights Division of 1957 and 1964. By 1941, when the country was preparing to enter WWII, black leaders like A. Philip Randolph, with the help of the First Lady, asked for integration in the military and condemnation of race discrimination therein. Although the President declined the integration, he promised to pass an executive order (Executive Order 8802) whereby he barred discrimination in war-related industries, and created the Fair Employment Practices Commission (FEPC), the function of which was to investigate complaints of discrimination and overturn segregation in the field. The E0 8802 read: 
There is established in the Office of Production Management a Committee on Fair Employment Practice, which shall consist of a chairman and four other members to be appointed by the President. The chairman and members of the Committee shall serve as such without compensation but shall be entitled to actual and necessary transportation, subsistence, and other expenses incidental to performance of their duties. The Committee shall receive and investigate complaints of discrimination in violation of the provisions of this order.

In a memorandum sent to government department heads on September $3^{\text {rd }} 1941$, the President recommended government agencies and departments to open their doors to qualified workers no matter their skin color or origin. He wrote,

With the view to improving the situation, it is my desire that all departments and independent establishments in the Federal Government make a thorough examination of their personnel policies and practices to the end that they may be able to assure me that in the Federal Service the doors of employment are open to loyal and qualified workers regardless of race, creed, or national origin.

By the end of the War, African Americans could finally hold war-industry jobs. Thousands of them quitted farm and domestic work, seeking better paid jobs in the North and West. The War helped Roosevelt take action against discrimination. The Executive Order 8802 could also bring economic benefits gained by the prosperity of the war to African Americans. Consequently, racial tensions progressively spread, leading up to severe race riots. Roosevelt responded by sending federal troops in many states to help calm down the situation. When African American servicemen came back to the United States after the WWII was over, segregationist policies of treating black veterans threatened stability in the country. Once again Roosevelt was required to ban discrimination and protect black civil rights.

Roosevelt, too, helped safeguarding black civil rights through the appointments he made to the Supreme Court after the constitutional war of 1937. Hugo Black and Stanley Reed appointed in 1937 and 1938 respectively paved the way to desegregation decisions through landmark decision in Missouri ex rel. Gaines $V$. Canada which validated a challenge against the University of Missouri Law School. In the course of time, most of Roosevelt's appointees to the Supreme Court joined Black and Reed in defending black civil liberties. African Americans could ultimately enjoy equality in education, transportation, and elections through a series of cases such as Mitchell V. U. S. (1941), among many others. In 1954, Roosevelt's appointees dismantled Jim Crow Codes and ruled against "separate but equal clause" through Brown V. Board of Education.

The First Lady Eleanor Roosevelt met their leaders, visited black communities, and addressed to them in her speeches as "my people"; and she helped African American leaders be closer to the President. This marked an important shift in the electoral behavior. Prior to the passage of the New Deal, African Americans voted for the "Party of Lincoln". By
1936, they voted for Democrats. They put an end to the long allegiance to the Republican Party, and became an important voting bloc for Democratic Party. Robert Higgs (1997) explained this electoral historic shift by the relief payment African Americans received thanks to some New Deal measures. This was rather a political support than a social one, stated Higgs. ${ }^{2}$

However, because of the Poll tax almost all African Americans were disenfranchised in Southern states. As response to a petition sent to him to urge the abolition of the Poll Tax on the ground that those disenfranchised were sent "far-off battle fronts of the world to fight corruption", President Roosevelt suggested to his Attorney General Francis Biddle to consider the constitutionality of the Poll Tax. The Attorney General did not carry on any court actions. The Roosevelts did, however. They tried hard to repeal the tax at the state level. Then, southern states, one by one, repealed the Poll Tax. Roosevelt's endeavor to abolish the Poll Tax which started in 1939 led in motion to the adoption of the Twenty-fourth Amendment. To sum up, Roosevelt did not help enhance African Americans' conditions through New Deal measures but also through other orders and actions he undertook with the First Lady to vanquish provisions which extended back to colonial days, just as he did for American Indians.

\subsection{New Deal and Indian Americans}

As for American Indians, there was a clear cut with past discriminatory policies through the designation of Indian Reorganization Act (the Wheeler-Howard Act of 1935), also referred to as the Indian New Deal. Indians were given right to manage their own affairs and lands ownership. The Act was intended to replace the Dawes Act of 1887. In retrospect, federal government provided lands to Native Americans but this created more problems between Indians and the U S army. To settle down the conflicts, Indians were forced onto reservations where they could manage their own affairs and preserve their traditions and culture. Yet, conflicts were not solved once and for all.

Whites engaged in endless conflicts with Native Americans about land issues. In the course of time, Whites rallied for the assimilation of Native Americans to make end to their "barbaric" traditions. Thus, Indians could become "true" Americans. This idea became embodied within the Dawes Act. Under the Act, the President was bestowed with an authority to confiscate and redistribute Natives' tribal lands. Indians who accepted to live in individual parcels were allowed to gain $\mathrm{U} S$ citizenship. Indian landholdings decreased from 139 million acres in 1880 to 48 million acres in 1928. Some Indians sold their lands to White farmers. Although the 1920s were prosperous years in the United States, Indians' per capita income was less than $\$ 200$ per year. The assimilation policy was even worse; Indians suffered cultural disintegration. Initiatives to improve Indian

2 Gavin Wright (2010), too, pointed out to Roosevelt's Machiavellian will to spend money to be reelected. 
conditions had clearly failed. Efforts to disable the allotment process, to establish tribal councils to impose taxes on the leased lands, and to found corporations which would manage tribal resources were all engulfed by the Great Depression.

The Roosevelt administration pioneered amending the Dawes Act. In 1933, Harold Ickes, Secretary of the Interior, recommended President Roosevelt to nominate John Collier, the spokesman for the militant American Indian Defense Association, as Commissioner of Indian Affairs. Collier advanced approaches which emphasized community participation. Local rural communities could be integrated within the federal policy process, under the Indian Service. Senator Burton K. Wheeler of Montana and Congressman Edgar Howard of Oklahoma introduced a bill to Congress with provisions for the ultimate diminution of allotment and restrictions of selling Indian lands. They suggested financing Indians with credit fund of $\$ 10$ million to help them purchase new lands. The Interior Department could therein buy lands for landless Indians.

The bill encountered serious oppositions from Western representatives and politicians as it allowed tribal governments to achieve consolidation via forcing landowners to sell their lands to the tribe or exchange them for shares in tribal corporations. The Wheeler-Howard Act was then signed into law as the Indian Reorganization Act of 1934. It was an all-inclusive act that mingled the views of reformers of Indian Affairs and of Western politicians who defended Western interests. In the economic sphere, tribal governments' interference in regulating businesses had been limited. With regard to land ownership, Indians' lands increased by 7.400 .000 acres as $\$ 12$ million were used to finance tribal enterprises in livestock, lumbering, land and water reclamation, and tourism. Thanks to the Act, Indians got expanded activity in the political scene, too.

Unlike the Dawes Act, the Indian New Deal promoted a strong tribal identity and self-determination, putting aside federal government frivolous policy toward Indians. In his article entitled the Native American New Deal, Graham D. Taylor stated,

Collier's administration did more to improve the physical and psychological conditions of Indian life than any administration before or since.... the Collier period marked the one instance in the grim history of relations between the Indian and the White governments where a genuine and farsighted effort was made to bridge a cultural chasm and allow the Indians to build a new society on the foundations of traditional institutions. (Taylor 1999 218)

In spite of this success, the Organization Act met resistance from some tribes. Cultural and communal unity was not yet revived. This failure is not thoroughly related to administrative misdemeanors. Minorities like the full-blood group argued about the authority bestowed within the tribal council. To avoid friction among Indians, advisers from different federal agencies divided the projects among and between different Indian minorities. Thus, more cohesion was achieved. Any systematic attempt to obstruct reorganization goals was to be blotted vocally. Such success is attributed to the Roosevelt administration.

\section{Conclusion}

FDR promised a "new deal for the American people", though at the outset it did not voice minorities like women, African Americans, and Indian Americans. Upon the whole, the New Deal had its efficiencies and inefficiencies. A fair assessment would reveal that initiatives that changed the relationship of the federal government and the American people, and promoted a social welfare; and the long-term developments of the American society are to be acknowledged to the New Deal. New Dealers did not ignore the failures, the weaknesses, and the gaps within their programs, and wished to refine them in due course as deficiencies were exposed and problems were identified. Black problems, to name only this, could elucidate this view. Agencies like PWA, WPA, and Farm Security Administration reflected the significant change in treating Blacks which was far from White preoccupations before. The pledge to promote relief programs for all the segments of the American society was achieved in motion.

\section{References}

[1] Allison J. Robert. History in Dispute, Vol. 3. American Social and Political Movements, 1900-1945: Pursuit of Progress. Detroit: St James Press, 1999.

[2] Badger Anthony J. The New Deal: The Depression Years 1933-1940. USA: Macmillan Press LTD, 1989.

[3] Bernanke B. S. Essays on the Great Depression. USA: Princeton University Press, 2000.

[4] Biles Roger. A New Deal for the American People. Illinois: Northern Illinois University Press, 1991.

[5] Ferrarra P. J., and Tanner M. A New Deal for Social Security. USA: Cato Institute Press, 1998.

[6] Gordon C., New Deal: Business, Labor, and Politics in America 1920-1935. Great Britain: Cambridge University Press, 1994.

[7] Higgs Robert. Crisis and Leviathan: Critical Episodes in the Growth of American Government. Oxford: Oxford University Press, 1987.

[8] Irons J. Testing the New Deal: the General Strike of 1934 in the American South. USA: University of Illinois Press, 2000.

[9] Weiss Nancy J. Farewell to the Party of Lincoln: Black Politics in the Age of FDR. Princeton: Princeton University Press, 1983.

[10] Woy Jean (Ed). Problems in American Society: the New Deal. USA: Houghton Mifflin Company, 1999. 